УДК 669.018.2:629.33

\title{
DEVELOPMENT OF HIGH STRENGTH STEEL SHEET WITH IMPROVED STRAIN HARDENABILITY FOR AUTOMOTIVE APPLICATION
}

\author{
Madhawan Chandrawanshi, Assistant Manager, \\ New Product Development (madhawan. chandrawanshi@jsw. in) \\ Rajan Kumar Singh, Manager, New Product Development \\ Sudharshan R., Assistant Manager, New Product Development
}

JSW Steel Ltd, Vijayanagar works

Toranagallu, Karnataka, 583275

\begin{abstract}
Advance high strength steel with minimum UTS of $780 \mathrm{MPa}$ is industrially developed utilizing continuous annealing line (CAL) and Gleeble thermo mechanical simulation. An outline of superior elongation, improved strain hardenability, enhanced strength of developed Fe-C $-\mathrm{Mn}-\mathrm{Si}$ TRIP assisted steel is described. Correlation amid Simulated result and industrially annealed steel are stabilized for microstructure and mechanical property. Annealing condition is optimized for best combination of strength and formability accordingly. CCT diagram for the selected composition from JMatPro is utilized to optimize rapid cooling rate and over aging section temperature. Final microstructure of developed steel comprises tempered martensite, granular bainite with retained austenite distributed in polygonal ferrite matrix. An evaluation of developed TRIP steel is carried out with the help of microstructure and XRD analysis. It was concluded that strain hardening coefficient of new steel is comparable to that of drawing grades attributable to about $13 \%$ retained austenite in microstructure.
\end{abstract}

Keywords: TRIP steel, retained austenite, continuous annealing, XRD, transformation, automotive steel, heat treatment.

DOI: $10.17073 / 0368-0797-2019-9-827-832$

\section{INTRODUCTION}

Lately TRIP assisted steel are in extensive demand for automotive application owing to their excellent strength ductility combination. The concern of strict global environment regulation to reduce tail pipe emission and improved fuel efficiency by BIW weigh reduction has further pushed the use of AHSS steels in automotive [1]. Since TRIP steel offer better combination of enhanced fatigue resistance and drawability, they are considered for novel highly formable cold-rolled steel sheet for automobile body application [2]. The strength deformation combination is attributed to TRIP phenomenon where strain-induced phase transformation of retained austenite (RA) renders excellent strain hardenability ( $n$-value) [3]. While evaluating TRIP assisted steel with Ferrite-Martensite Dual phase grade of same strength, the former shows improved strain hardenability and elongation due to TRIP effect. Additionally, improved formability of
TRIP-steel can be attributed to their composite like deformation behaviour where retained austenite transformation assists in strain distribution in the softer bainite and ferrite constituents [4-6]. The improved fatigue life is attributed to relaxation of high stressed field during fatigue by transformation of retained austenite to Martensite [7 - 10]. With said advantages, this study outlines the industrial development of next generation TRIP assisted steel with a tensile strength of atleast $780 \mathrm{MPa}$.

\section{EXPERIMENTAL}

Steel slab of $220 \mathrm{~mm}$ thickness with chemical composition (Table 1) as per DIN EN 10338 - HCT780T) grade is industrially produced though basic oxygen furnace (BOF) RH degasser route in steel melting shop (SMS) and continuously casted subsequently at industrial slab casting machine. Slabs are hot rolled to $2.4 \mathrm{~mm}$ at 7 -strand hot strip

Chemical Composition of HCT780T- TRIP steel

Таблица 1. Химический состав ПНП-стали НСТ780Т

\begin{tabular}{c|c|c|c|c|c|c|c|c}
\hline Grade & $\begin{array}{c}\mathrm{C} \\
(\mathrm{Max})\end{array}$ & $\begin{array}{c}\mathrm{Mn} \\
(\mathrm{Max})\end{array}$ & $\begin{array}{c}\mathrm{Si} \\
(\mathrm{Max})\end{array}$ & $\begin{array}{c}\mathrm{P} \\
(\mathrm{Max})\end{array}$ & $\begin{array}{c}\mathrm{S} \\
(\mathrm{Max})\end{array}$ & $\begin{array}{c}\mathrm{Cr}+\mathrm{Mo} \\
(\mathrm{Max})\end{array}$ & $\begin{array}{c}\mathrm{Nb}+\mathrm{Ti} \\
(\mathrm{Max})\end{array}$ & $\begin{array}{c}\mathrm{V} \\
\text { (Max) }\end{array}$ \\
\hline HCT780T & 0.220 & 2.000 & 2.000 & 0.020 & 0.005 & 0.300 & 0.150 & 0.050 \\
\hline
\end{tabular}


mill (HSM) keeping the hot finish temperature above A3 and coiling in the range from $550-600^{\circ} \mathrm{C}$. Acid pickling and cold rolling $(1.2 \mathrm{~mm})$ is carried out at pickling line tandem with cold rolling mill (PLTCM). Cold rolled samples are simulated at Gleeble 3800 thermo mechanical simulator and processed at industrial Continuous annealing line (CAL) respectively. JMatPro simulation software is utilized to generate composition based CCT curves. Tensile tests are carried out as per ISO 6892-1:2009(E) standard in Zwick Roell-100KN tensile testing machine. Microstructure examination is carried in Carl Zeiss Optical microscope at and Hitachi Scanning Electron microscope utilizing SE mode. XRD analysis is done at PANalytical - Empyrean $\mathrm{X}$-ray difractometer with $\mathrm{Cu}-\mathrm{K} \alpha$ Source.

\section{RESULT AND DISCUSSIONS}

\section{Hot Rolled and Cold Rolled Microstructure}

\section{and Properties}

As given in Fig. 1a, Ferrite-pearlite microstructure at hot rolled (HR) stage is broken down to elongated ferrite and pearlite microstructure with small precipitates of cementite (Fig $1 b$.) post $50 \%$ cold rolling. Pearlitic microstructure at $\mathrm{HR}$ stage is due to high coiling temperature $\left(>550^{\circ} \mathrm{C}\right) \mathrm{du}-$ ring hot rolling which is above the bainite start temperature as given in CCT diagram of sleeted steel composition.

\section{CCT Curve and Annealing cycle}

Fig. $2 a$ and Fig. $2 b$ demonstrate TTT and CCT curves respectively acquired from JMatPro Thermo-Physical simulation software to calculate various critical temperature for given TRIP steel composition. As seen in Fig. $2 a$ and Fig. $2 b$, Bainite start temperature $\left(B_{s}\right)$ is close to $480{ }^{\circ} \mathrm{C}$ where as $M_{s}$ temperature is close to $380{ }^{\circ} \mathrm{C}$. Based on the CCT curve, Gleeble and in line CAL trials are carried out to optimize the annealing condition for better strength - ductility combination. Fig. 3 depicts typical CAL/Gleeble annealing cycle with different over aging temperature tryouts for Cold rolled Closed Annealed (CRCA) steel sheet.

\section{Microstructure Post Continuous Annealing}

Typical mechanical property of Continuous Annealed and Gleeble simulated samples are listed in Table 3. As given in Table 3, excellent combination if Strength (UTS $>850 \mathrm{MPa}$ ) with superior elongation and strain hardenability could be achieved post annealing. Annealing with Soaking temperature of $800{ }^{\circ} \mathrm{C}$ with cooling rate $<25^{\circ} \mathrm{C} / \mathrm{s}$ and over aging temperature of $450{ }^{\circ} \mathrm{C}$ lead to above listed mechanical properties.

Fig. $4 a$ and Fig. $4 b$ shows the SEM and Optical micrograph of CAL annealed sample annealed at A3-20 ${ }^{\circ} \mathrm{C}$. Rapid cooling end and Overaging section temperatures
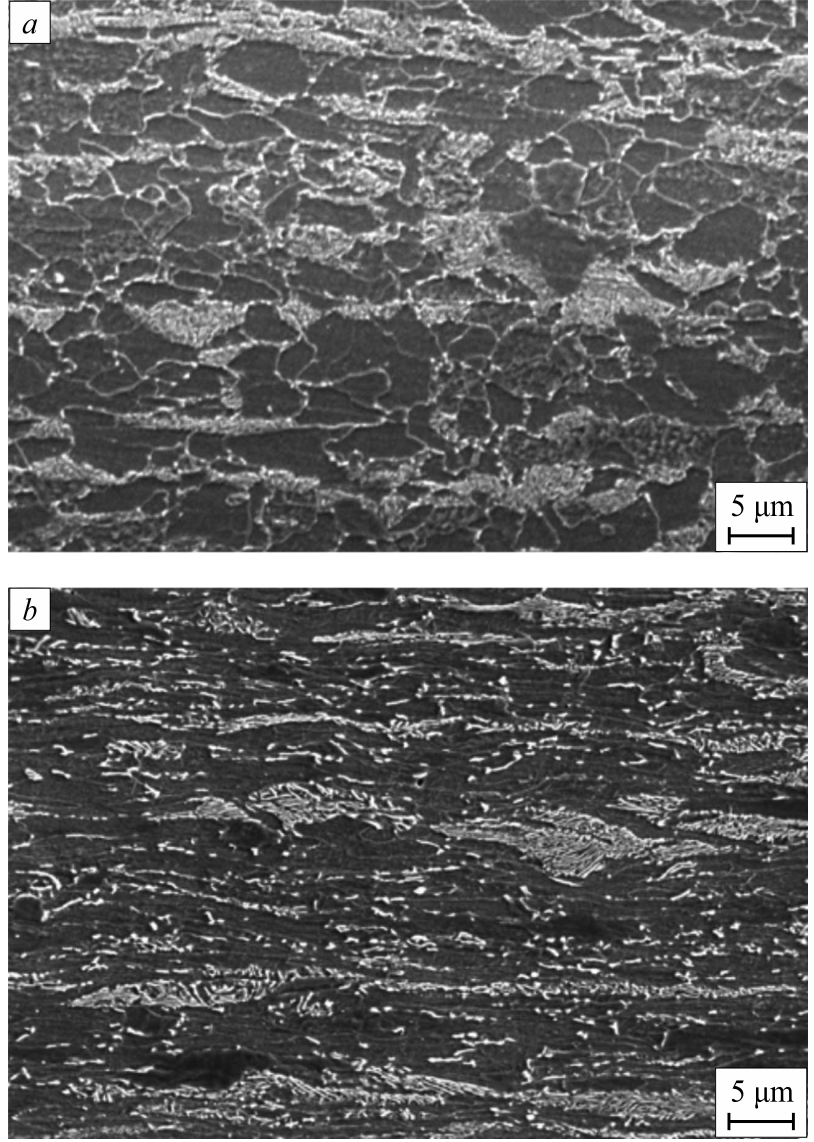

Fig. 1. SEM Micrograph of TRIP Steel, $\times 2000$ : $a$-hot-rolled; $b$ - cold rolled

Рис. 1. СЭМ-микрография ПНП-стали, $\times 2000$ : $a$ - горячекатаная; $b$ - холоднокатаная

Table 2

\section{Mechanical properties Hot rolled and Cold Rolled Samples HCT780T steel}

Таблица 2. Механические свойства горячеи холоднокатаных образцов стали НСТ780Т

\begin{tabular}{|c|c|c|c|}
\hline Grade & YS (MPa) & UTS(MPa) & El \%, 50 gl \\
\hline Hot Rolled & $660 \pm 15$ & $778 \pm 12$ & $18 \pm 1$ \\
\hline Cold Rolled (Full Hard) & $1050 \pm 10$ & $1170 \pm 15$ & $5 \pm 1$ \\
\hline
\end{tabular}

are kept at $B_{s}-40{ }^{\circ} \mathrm{C}$ and $B_{s}-30{ }^{\circ} \mathrm{C}$ respectively, where as $B_{s}$ is Bainite start temperature for given composition calculated from JmatPro. Optical micrograph shows island of Bainite, Retained Austenite (RA) along with small fraction of Martensite (M) distributed in Recrystallized ferrite matrix. Fig. $4 c$ shows distribution of different microstructural constituents where Ferrite is shown as Green, Bainite as Blue and Retained Austenite/Martensite as brown color. XRD diffraction pattern given in Fig. $4 d$ suggested about $13 \%$ of RA in the microstructure where as $25 \%$ Bainite and $55 \%$ Ferrite are calculated from Optical micrograph. Martensite fraction $(\sim 7 \%)$ is calculated from deducting 

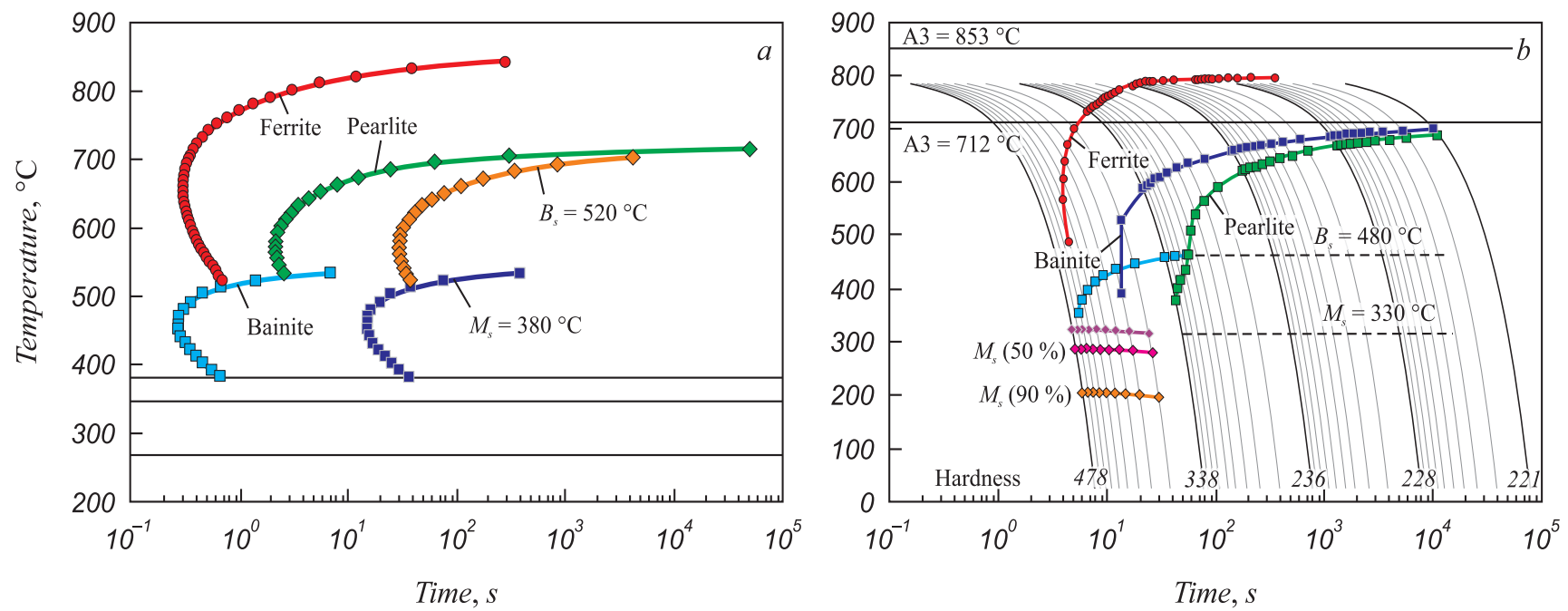

Fig. 2. TRIP Steel of selected Composition: $a-$ TTT diagram; $b-$ CCT diagram

Рис. 2. ПНП-сталь выбранного состава: $a$ - диаграмма время-температура-выделение; $b$ - термокинетическая диаграмма

RA fraction from RA $+M$ fraction which is about $20 \%$ for given sample.

\section{Annealing Parameters vs. Mechanical Properties}

Cold rolled coils and full hard samples are processed at CAL and Gleeble Thermo mechanical simulator respectively at different Soaking (Annealing) and Overaging Temperatures. Mechanical properties are evaluated for optimum strength-ductility balance. Soaking temperature (SS) is varied from $\mathrm{A} 3-100{ }^{\circ} \mathrm{C}$ to $\mathrm{A} 3+10{ }^{\circ} \mathrm{C}$, where $\mathrm{A} 3$ is upper critical temperature calculated in JMatPro. To study the effect of soaking temperature, rapid cooling (RCS) and Overaging (OAS) temperatures were kept constant as $B-40{ }^{\circ} \mathrm{C}$ and $B-30{ }^{\circ} \mathrm{C}$ respectively. As evident from Fig. $5 a$, superior strength and elongation combination can be achieved at soaking temperature of $\mathrm{A} 3-20{ }^{\circ} \mathrm{C}$ having UTS of atleast $850 \mathrm{MPa}$ and Elongation more than $25 \%$. It is also observed that increasing SS over A3 doesn't have

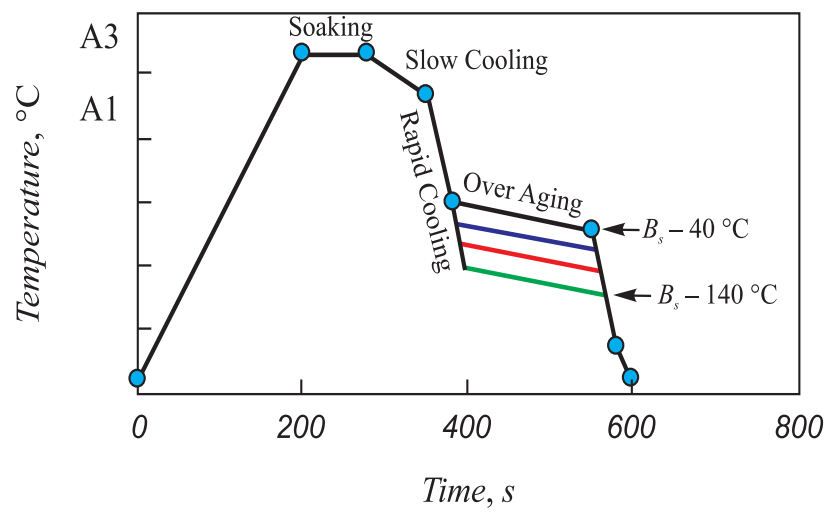

Fig. 3. Typical CAL annealing Cycle

Рис. 3. Стандартная схема отжига на ЛНО any significant impact on strength or elongation as keeping soaking temperature above A3 result in larger austenite grain size degrading the final strength. Keeping SS to A3-100 ${ }^{\circ} \mathrm{C}$ (Fig. $5 a$ ) resulted in poor elongation as at such a low temperature of intercritical annealing, the amount of retained austenite in final microstructure is not sufficient to give sufficient TRIP effect.

To analyze the impact of Overaging temperature as given in typical annealing cycle (Fig. 3), OAS in CAL is varied from $B_{s}-130$ to $B_{s}+140^{\circ} \mathrm{C}$ while keeping the Soaking temperature constant at A3-20 $0^{\circ} \mathrm{C}$. Similar cycle is simulated in Gleeble as well. Rapid cooling end temperature is always kept OAS $+10^{\circ} \mathrm{C}$ for each trial. As evident from Fig. $6 b$ an optimum combination of Strength $(855 \mathrm{MPa})$, Elongation $(25 \%)$ and excellent strain hardenability ( $n$-value) of 0.22 is achieved at OAS temperature of $B_{s}-40{ }^{\circ} \mathrm{C}$ at CAL. The result is attributed to $13 \%$ RA along with $55 \%$ ferrite and $25 \%$ Bainite in microstructure (Fig. $4 b$ to Fig. $4 d$ ). Keeping OAS temperature down to $B_{s}-130{ }^{\circ} \mathrm{C}$ (Fig. $6 a$ ) results in elevated strength of $903 \mathrm{MPa}$ due to increased Martensite phase fraction; however the resultant elongation drops significantly due to lower retained austenite $(<2 \%)$ in microstructure.

Table 3

\section{Typical Mechanical properties of Trip 780 steel post Annealing}

Таблица 3. Стандартные механические свойства ПНП-стали 780 после отжига

\begin{tabular}{c|c|c|c|c}
\hline Grade & YS $(\mathrm{MPa})$ & UTS $(\mathrm{MPa})$ & $\mathrm{El} \%, 50 \mathrm{gl}$ & $n$-value \\
\hline CAL & $480 \pm 9$ & $854 \pm 12$ & $25.0 \pm 1.0$ & $0.23 \pm 0.01$ \\
\hline Gleeble & $468 \pm 13$ & $843 \pm 15$ & $24.5 \pm 1.5$ & $0.22 \pm 0.01$ \\
\hline
\end{tabular}



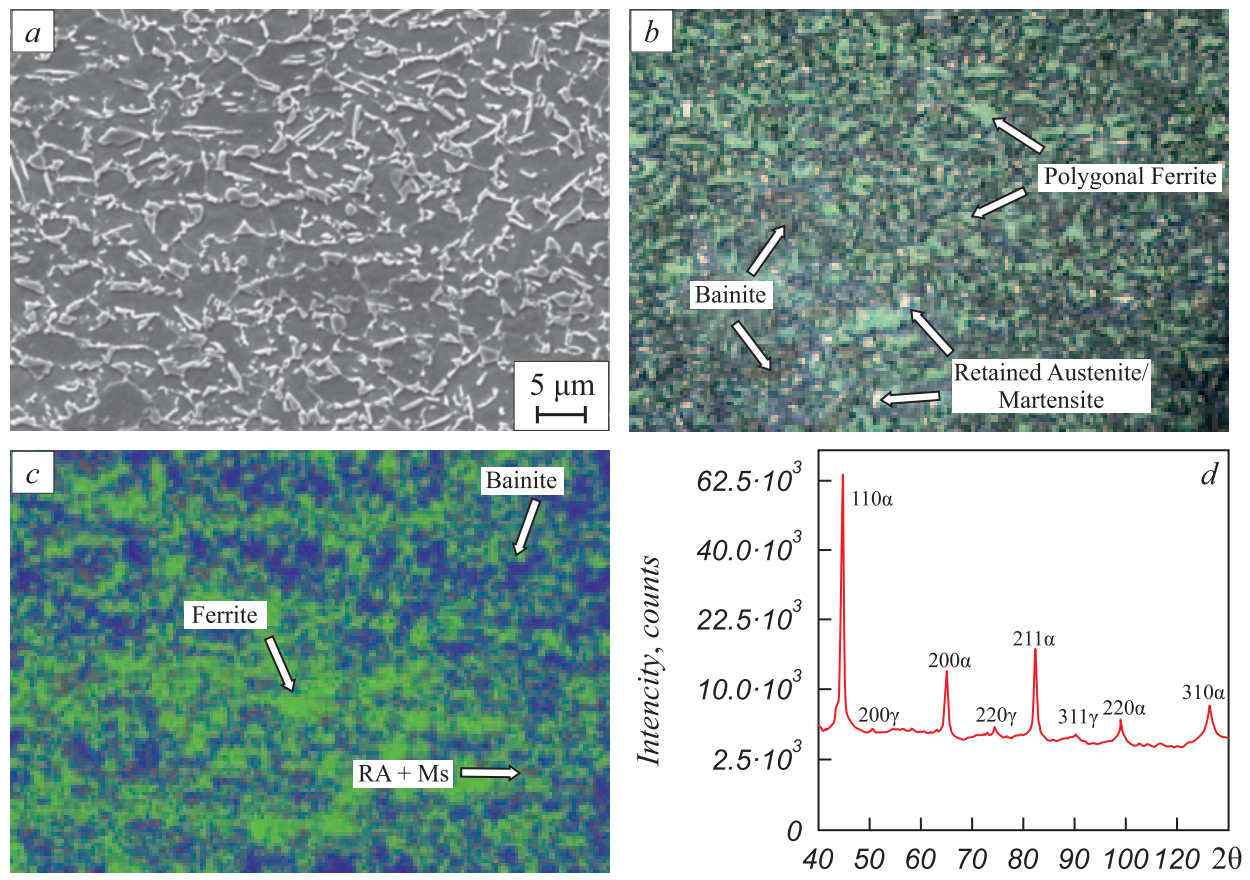

Fig. 4. Continuous annealed microstructures of 780 TRIP steel:

$a$-SEM micrograph; $b$ - optical micrograph; $c$ - color map of distribution of different phases; $d$ - XRD diffraction pattern

Рис. 4. Непрерывно-отожженные микроструктуры ПНП-стали 780:

$a$ - СЭМ-микрофотография; $b$ - оптическая микрофотография; $c$ - цветная карта распределения разных фаз; $d$ - дифракционная рентгенограмма
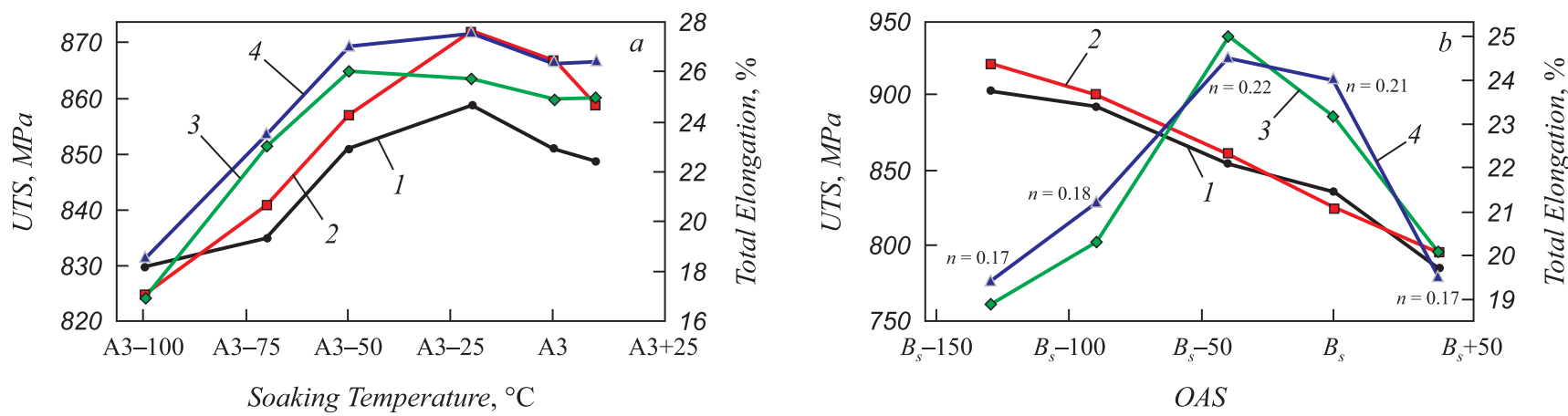

Fig. 5. Dependences for CAL and Gleeble Simulation: $a$ - soaking temperature vs. UTS/El $\% ; b$ - overaging section temperature vs. UTS/El $\%$; 1 - UTS - CAL; 2 - UTS - Gleeble; 3 - El \% - CAL; 4 - El \% - Gleeble

Рис. 5. Зависимости для моделирования ЛНО и Gleeble: $a$ - температуры выдержки от предела прочности на разрыв/El \%; $b$ - температуры старения секции от предела прочности на разрыв/El \%; 1 - UTS - CAL; 2 - UTS - Gleeble; 3 - El \% - CAL; 4 - El \% - Gleeble

\section{CONCLUSION}

With selective combination of chemical composition and annealing parameters, HCT 780T Trip steel has been successfully developed industrially and validated through Gleeble simulation. Resultant steel confirm improved strength-drawability combination with excellent strain hardenability. It is also concluded that Keeping SS temperature of $\mathrm{A} 3-30{ }^{\circ} \mathrm{C}$ and OAS temperature of $B_{s}-40{ }^{\circ} \mathrm{C}$ gives optimum result with $13 \%$ retained austenite for given composition. However, keeping OAS at reduced level of
$B_{s}-140{ }^{\circ} \mathrm{C}$ and Soaking $\mathrm{A} 3-100^{\circ} \mathrm{C}$ resulted in poor elongation.

\section{REFERENCES}

1. Lee C.G., Kim S.J., Lee T.H. etc. Effects of volume fraction and stability of retained austenite on formability in a $0.1 \mathrm{C}-1.5 \mathrm{Si}-1.5 \mathrm{Mn}-$ $-0.5 \mathrm{Cu}$ TRIP-aided cold-rolled steel sheet. Mater. Sci. Eng. A. 2004, vol. 371 , no. $1-2$, pp. $16-23$.

2. Tao Fu-Yong, Jing Liu etc. Effects of cold rolling reduction on retained austenite fraction and mechanical properties of high-Si TRIP steel. Journal of Iron and Steel Research International. 2013, vol. 20 , no. 5 , pp. 50-56. 


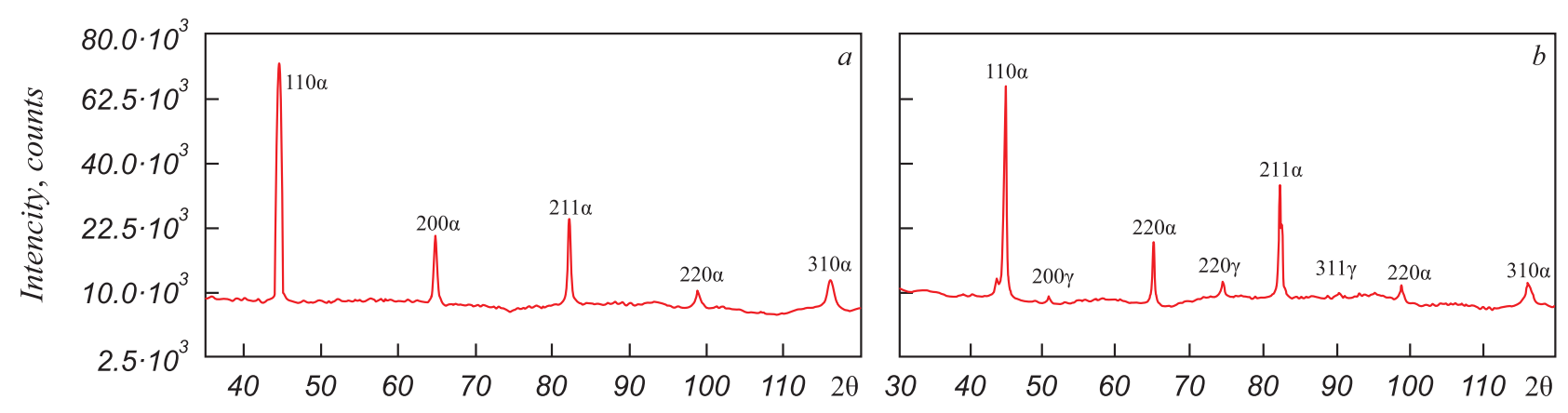

Fig. 6. XRD pattern of the sample processed at: $a-\mathrm{OAS} B_{s}-140^{\circ} \mathrm{C} ; b-\mathrm{OAS} B_{s}-40^{\circ} \mathrm{C}$

Рис. 6. Рентгенограмма образца после выдержки в масле при: $a-140^{\circ} \mathrm{C} ; b-40^{\circ} \mathrm{C}$

3. Yong Tian, Jhuang Li. Effects of warm deformation on mechanical properties of TRIP aided $\mathrm{Fe}-\mathrm{C}-\mathrm{Mn}-\mathrm{Si}$ multiphase steel. Journal of Iron and Steel Research International. 2012, vol. 19, no. 6, pp. 47-52.

4. Bhadeshia H.K.TRIP-assisted Steels? ISIJ Int. 2002, vol. 42, no. 9, pp. 1059-1060.

5. S.Yue, Chiro Diet etc. Thermomechanical processing effects on $\mathrm{C}-\mathrm{Mn}-\mathrm{Si}$ TRIP steels. Journal of the minerals metals \& materials Society. 1997, vol. 49, no. 9, pp. 59-61.

6. Sakuma Yasuharu, Kimura Noritoshi etc. Next-generation highstrength sheet steel utilizing transformation-induced plasticity (TRIP) effect. Nippon Steel Technical report. 1995, no. 64: Special Issue on Materials for Automotice Use, article 4.

7. Hofmann H., Mattissen D., Schaumann T.W. Advanced cold rolled steels for automotive applications. Steel Research Int. 2009, vol. 80, no. 1 , pp. 22-28.
8. Wang Li, Jin L., Xia, Q., Xun Z. Application of TRIP steel to replace mild steel in automotive parts. In: Int. Conf. on New Developments in Advanced High Strength Steel Sheetsproceedings. Warrendale, PA, Association for Iron \&. 2004, pp. 31-38.

9. Sakuma W., Matsummura O., TakechiH. Mechanical properties and retained austenite in intercritically heat-treated bainite-transformed steel and their variation with $\mathrm{Si}$ and $\mathrm{Mn}$ additions. Metal. Trans. A. 1991, vol. 22, no. 2, pp. 489-498.

10. Vasilakos A.N, Papamantellos K., Hiademenopoulos H. etc. Experimental determination of the stability of retained austenite in low alloy TRIP steels. Steel Research Int. 1999, vol. 70, no. 11, pp. 466-471.

Received December 19, 2017

Revised December 20, 2017

Accepted August 8, 2019

\section{РАЗРАБОТКА ВЫСОКОПРОЧНОГО СТАЛЬНОГО ЛИСТА \\ С УЛУЧШЕННОЙ ДЕФОРМАЦИОННОЙ ПРОКАЛИВАЕМОСТЬЮ ДЛЯ АВТОМОБИЛЬНОЙ ПРОМЫШЛЕННОСТИ}

\section{Мадхаван Чандраванши, Райан Кумар Синхх, Судхар- иан $P$.}

\section{JSWSteel Ltd, Vijayanagar works, (583275, Индия, Карнатака,} Торанагаллу)

Аннотация. Передовая высокопрочная сталь с минимальным пределом прочности на разрыв 780 МПа была разработана промышленным способом с использованием линии непрерывного отжига (ЛНО) и термомеханического моделирования Gleeble. Разработанная $\mathrm{Fe}-\mathrm{C}-\mathrm{Mn}-\mathrm{Si}$ ПНП-сталь обладает повышенной деформационной прокаливаемостью, прочностью и относительным удлинением. Корреляция между моделируемым результатом и промышленно отожженной сталью видна по микроструктуре и механическим свойствам. Условия отжига оптимизированы для наилучшего сочетания прочности и формуемости. Термокинетическая диаграмма для выбранной JMatPro композиции используется для оптимизации скорости охлаждения и температурных режимов старения. Конечная микроструктура разработанной стали состоит из закаленного мартенсита и сфероидизированного бейнита с остаточным аустенитом, распределенным в полигональной ферритовой матрице. Оценка разработанной ПНП-стали проводилась с помощью оптического и рентгеноструктурного анализа. В результате ис- следований установлено, что коэффициент деформационного упрочнения новой стали сравним с коэффициентом упрочнения марок, содержащих приблизительно $13 \%$ остаточного аустенита в микроструктуре.

Ключевые слова: ПНП-сталь, остаточный аустенит, непрерывный отжиг, рентгеноструктурный анализ, трансформация, автомобильная сталь, термообработка.

DOI: $10.17073 / 0368-0797-2019-9-667-832$

\section{БИБЛИОГРАФИЧЕСКИЙ СПИСОК}

1. Lee C.G., Kim S.J., Lee T.H. etc. Effects of volume fraction and stability of retained austenite on formability in a $0.1 \mathrm{C}-1.5 \mathrm{Si}-1.5 \mathrm{Mn}-$ $-0.5 \mathrm{Cu}$ TRIP-aided cold-rolled steel sheet // Mater. Sci. Eng. A. 2004. Vol. 371. No. 1 - 2. P. $16-23$.

2. Tao Fu-Yong, Jing Liu etc. Effects of cold rolling reduction on retained austenite fraction and mechanical properties of high-Si TRIP steel // Journal of Iron and Steel Research International. 2013. Vol. 20. No. 5. P. $50-56$.

3. Yong Tian, Jhuang Li. Effects of warm deformation on mechanical properties of TRIP aided Fe-C-Mn-Si multiphase steel // Journal of Iron and Steel Research International. 2012. Vol. 19. No. 6. P. $47-52$. 
4. Bhadeshia H.K. TRIP-assisted Steels // ISIJ Int. 2002. Vol. 42. No. 9. P. 1059 - 1060.

5. S.Yue, Chiro Diet etc. Thermomechanical processing effects on $\mathrm{C}-\mathrm{Mn}-\mathrm{Si}$ TRIP steels // Journal of the minerals metals \& materials Society. 1997. Vol. 49. No. 9. P. $59-61$.

6. Sakuma Yasuharu, Kimura Noritoshi etc. Next-generation highstrength sheet steel utilizing transformation-induced plasticity (TRIP) effect // Nippon Steel Technical report. 1995. No. 64: Special Issue on Materials for Automotice Use, article 4.

7. Hofmann H., Mattissen D., Schaumann T.W. Advanced cold rolled steels for automotive applications // Steel Research Int. 2009. Vol. 80. No. 1. P. $22-28$.

8. Wang Li, Jin L., Xia, Q., Xun Z. Application of TRIP steel to replace mild steel in automotive parts // Int. Conf. on New Developments in Advanced High Strength Steel Sheetsproceedings. Warrendale, PA, Association for Iron \&. 2004. P. $31-38$.

9. Sakuma W., Matsummura O., Takechi H. Mechanical properties and retained austenite in intercritically heat-treated bainite-transformed steel and their variation with Si and Mn additions // Metal. Trans. A. 1991. Vol. 22. No. 2. P. $489-498$.

10. Vasilakos A.N., Papamantellos K., Hiademenopoulos H. etc. Experimental determination of the stability of retained austenite in low alloy TRIP steels // Steel Research Int. 1999. Vol. 70. No. 11. P. $466-471$.

\section{Информация об авторах:}

Мадхаван Чандраванши, помощник менеджера по разработке новых продуктов (madhawanchandrawanshi@jsw. in)

Райан Кумар Сингх, менеджер по разработке новых продуктов Судхаршан Р., помощник менеджера по разработке новых продуктов

Поступила в редакцию 19 декабря 2017 г После доработки 20 июля 2019 г. Принята к публикации 8 августа 2019 г. 